\title{
THE USE OF ANAGRAMS TO INCREASE STUDENTS' ENGLISH VOCABULARY MASTERY
}

\author{
Yugi Diraga Prawiyata \\ Universitas Muslim Nusantara Al Washliyah \\ yugidiraga@umnaw.ac.id
}

\begin{abstract}
The objective of the research was to find out whether Anagrams increased students' vocabulary mastery and to find out how was the students' mastery in learning vocabulary by using Anagrams. The subject of this research was the second year students of MTs Al Washliyah 32 Sei Bamban in academic year 2018/2019 which consisted of thirty people. In this research, it was applied the Classroom Action Research (CAR). Technique of collecting the data was to use a written test, in a certain topic applied in Anagram technique where the researcher made the indicators as the test consisted of twenty where each number amounts to 5. Then the researcher observed the students' action while the use of Anagram technique was implemented and also the students' opinion about the effectiveness of Anagram technique toward their vocabulary mastery. The result of the research showed that the students' score in the second cycle was higher (85-95) than the first cycle (68-90). In other words it indicated that the use of Anagrams really increase students' vocabulary mastery.
\end{abstract}

Keywords : vocabulary, mastery, anagrams

\section{INTRODUCTION}

Vocabulary is very essential for success to comprehend the language well, speak better, or compose a good writing; it is expected that learners have to increase their vocabularies (Nation, 1990:22). By mastering a number of vocabularies, we will able to conceive what we hear and read, and then we will be able to say what we want to speak and write.

Teaching vocabulary is one of the basic elements in achieving all four language skills. Similarly, Jordan (1997:149) also states that teaching vocabulary is such an important task in teaching English because vocabulary achievement relates to all language learning and it is concern to all four language skills.

Based on the researcher's review in the field, he found that many students still had low vocabulary mastery. Moreover, when having an interview with the English teachers, the researcher can conclude that the students hardly to learn vocabulary. Vocabulary is one basic thing students must master to be good at English lesson, but unfortunately the teacher does not have many good ways or strategies which attract students to learn English.

English is not our native language; so many students have many problems in mastering English words. They are not aware of the importance of studying vocabulary. They feel bored with the way of teaching in which they are asked to find out the meanings of difficult words in dictionary and then they try to memorize the words. It seems that the use of different method in teaching vocabulary is considered as one solution. One of the methods that can be used to solve the problem in teaching English is by using game.

One of the language games to teach vocabulary is by using Anagram. Teacher who teaches vocabulary lesson to their students in classroom can apply it.

Anagram is not only game but it is also having an educational value. By using Anagram, it makes students to get many new words and enjoy the word game while 
they are studying the vocabulary and also will motivate and encourage the students in learning.

\section{METHOD}

\subsection{Design of the Research}

In this research, it is applied the Classroom Action Research (CAR). The Classroom Action Research (CAR) is defined as one of problem solving strategies in which uses the action, and the process of skill development to detect and solve the problems (Hopkins in Wiriaatmadja, 2008: 66).

It can be concluded that the Classroom Action Research purposes to solve the problems and it is reflective. In this case, the researcher and the teacher build collaboration in learning activity until the researcher gets the same reason and understanding about the problem. So the research will be done in the effort of the implementation of approximate systems in teaching vocabulary skill.

This Classroom Action Research (CAR) is completely done through several cycles. Each cycle comprises several integrated points such as students' learning achievement, the teachers' teaching procedures (lesson plan, teachers' action, observation and the last is the reflection stage where a teacher paid much attention on the present results for the sake of preparing the next cycles.

\subsection{Subject of the Research}

The subject of this research is the second year students of MTs Al Washliyah 32 Sei Bamban in academic year 2018/2019 which consists of thirty people.

\subsection{Instrument of the Research}

To collect data, the researcher makes the test, the test suites the curriculum of the second year students of junior high school. The test used belongs to written test, which is in an informal situation and expression to the teacher about certain topic applied in Anagram technique.

\subsection{Technique of Analyzing the Data}

Based on the explanation above, the researcher makes the indicators as the follows: the test consists of twenty where each number amounts to 5 . It means that the highest score is 100 .

Then the researcher observed the students' action while the use of Anagram technique was implemented and also the students' opinion about the effectiveness of Anagram technique toward their vocabulary mastery.

\section{FINDING AND DISCUSSION}

\subsection{Preliminary Data}

Before conducting action research, the researcher gave a pre-test to the students. The purpose of pre-test was to know students' achievement in vocabulary. They were 30 students who followed the test.

In this research, the researcher found that the students' score was weak. It was shown in the percentage of the class success is $27 \%$. It meant that the students who passed the test on the pre-test were 27 $\%$, while $73 \%$ was unsuccessful.

Based on the result above, the average of students in pre-test was poor. The researcher decided to use another technique to make students interested in the learning process in order to improve students' vocabulary achievement in by using Anagrams.

\subsection{First Cycle}

In this cycle it was conducted two meeting, second and third meeting. Each meeting had vocabulary test and in the third meeting, the researcher gave the result of the test.

From the test, the researcher found that the percentage of the class success was $77 \%$ and there were $77 \%$ of the students passed the test, while $23 \%$ were failed. Based on the criteria of success in vocabulary achievement where the research can be said successful if the students got 70 up to $100(85 \%)$. So, this 
research was not successful yet. So, the researcher had to arrange the second cycle.

\subsection{Second Cycle}

The second cycle was the process of improving the first cycle. The activities were almost the same as the first cycle. The result of the test in this cycle was very satisfied. It had showed the improvement. It could be seen that the lowest score got by the student was 85 and the highest score was 95 .

\section{CONCLUSION}

Based on the pre-test of vocabulary achievement in the preliminary study, the students' achievement was far from being successful. There were only $26 \%$ of 30 students who passed at the test in the preliminary study. To improve students' vocabulary mastery, the researcher treated them by using Anagrams in a classroom action research.

In the first cycle, the amount of the students who passed the test was increasing. There were $76 \%$ of students who passed the test. It could have not indicated the percentage of success. Then the researcher obtained a successful research in the second cycle.

In the second cycle, it was found that the use of Anagrams motivated the students to learn more effectively through their active participation in learning English, and exactly increased students' vocabulary mastery. The result of this research in the second cycle was $100 \%$, and this research was stated success.

It can be concluded that the use of Anagram increases students' vocabulary mastery.

\section{REFERENCES}

Alqahtani, Mofareh. (2015). The Importance of Vocabulary in Language Learning and How to be Taught. Retrieved from International Journal of Teaching and Education; Vol. 3, No. 3; 2015

Anagram. Retrieved on 07 January 2018 fromhttp://www.anagramgenius.com/d efinition.html

Anagram. Retrieved on 07 January 2018 fromhttp://www.k12reader.com/term/a nagram/

Bachtiar, Maimunah. (2014). Improving Students' Vocabulary Achievement in Reading Recount Text through Anagram Technique. Retrieved from e-Journal of UNIMED

Geihkman, Yuliya. (2019). How Do You Learn Best? The 13 Best Ways to Learn English for Different Learning Styles. Retrieved in 21 July 2019 from https://www.fluentu.com/blog/english/ best-way-to-learn-english-vocabulary/

Hornby, A.S. (2010). Oxford Advanced Learner's Dictionary, 3th Edition. Paperback: Oxford University Press.

Jordan, R.R. (1997). English for Academic Purposes: A Guide and Resources Book for Teachers. Cambridge: University Press.

Napa. (1991). How to Teach Vocabulary. Bandung: Rineka Cipta.

Nation, I. S. P. (1990). Teaching and Learning Vocabulary. Boston: Heinle \& Heinle Publishers.

Rosadi, Ahdian. (2017). The Effectiveness of Anagram Technique in Teaching Vocabulary. Retrieved from Journal of Voices of English Language Education Society; Vol. 1, No. 1; April 2017 E-ISSN 2579-7484 